UDC 575.224.2

\title{
Surface plasmon resonance investigation of DNA hybridization on a sensor surface using gold nanoparticles modified by specific oligonucleotides
}

\author{
M. J. Matsishin ${ }^{1,2}$, A. I. Kucherov ${ }^{3}$, Iu. V. Ushenin ${ }^{4}$, A. M. Lyapin ${ }^{4}$, \\ A. M. Lopatynskyi ${ }^{2,4}$, V. I. Chegel ${ }^{2,4}$, A. E. Rachkov ${ }^{1}$ \\ ${ }^{1}$ Institute of Molecular Biology and Genetics, NAS of Ukraine \\ 150, Akademika Zabolotnoho Str., Kyiv, Ukraine, 03680 \\ 2 Institute of High Technologies, \\ Taras Shevchenko National University of Kyiv \\ 2, korp.5, pr. Akademika Hlushkova, Kyiv, Ukraine, 03022 \\ ${ }^{3}$ National Technical University of Ukraine "Igor Sikorsky Kyiv Polytechnic Institute" \\ 37, Pobedy av., Kyiv, Ukraine, 03056 \\ ${ }^{4}$ V. Ye. Lashkaryov Institute of Semiconductor Physics, NAS of Ukraine \\ 41, pr. Nauki, Kyiv, Ukraine, 03028 \\ oleksandr_rachkov@yahoo.com
}

\begin{abstract}
Aim. To investigate an influence of the oligonucleotide concentration on their immobilization on the surface of gold nanoparticles (AuNPs), and to study interactions between the AuNPs modified by various oligonucleotides and the oligonucleotides immobilized on the chip of the SPR-based DNA-sensor. Methods. Oligonucleotide immobilization on the surface of AuNPs was investigated by fluorescence spectrometry. The interactions of citrate-stabilized AuNPs modified by oligonucleotides with the oligonucleotides immobilized on the chip of the DNAsensor were studied by the surface plasmon resonance spectrometry. Results. The initial oligonucleotide concentration influences the level of their immobilization on the surface of citratestabilized AuNPs: up to $200 \mathrm{nM}$ the dependence was close to linear, and then saturation was observed at $\sim 26$ molecules per particle or $\sim 0.5 \times 10^{13}$ molecules $\mathrm{cm}^{-2}$. In contrast, the efficiency of immobilization gradually decreased with an increase in the initial oligonucleotide concentration. Using the SPR-based DNA-sensor, the efficient hybridization between oligonucleotides immobilized on the sensor chip and complementary oligonucleotides of various length (short T2-11m and long T2-18m) immobilized on the surface of AuNPs was demonstrated. In case of AuNPs modified by short oligonucleotides, efficient thermal and chemical regenerations of the bioselective element of the DNA-sensor were achieved. Conclusions. Oligonucleotide immobilization on the surface of AuNPs directly depends on the initial oligonucleotide concentration, whereas the initial oligonucleotide concentration and
\end{abstract}

C 2017 M. Matsishin et al.; Published by the Institute of Molecular Biology and Genetics, NAS of Ukraine on behalf of Biopolymers and Cell. This is an Open Access article distributed under the terms of the Creative Commons Attribution License (http://creativecommons.org/licenses/by/4.0/), which permits unrestricted reuse, distribution, and reproduction in any medium, provided the original work is properly cited 
the efficiency of their immobilization on the surface of AuNPs demonstrate the inverse relationship. The efficient hybridization of the oligonucleotides of various lengths immobilized on AuNPs with the oligonucleotides immobilized on the sensor surface as well as the possibility of thermal or chemical regeneration allow the sensor reuse and a strong amplification of the sensor signal.

Ke y w o r d s: gold nanoparticles, oligonucleotides, immobilization, surface plasmon resonance, DNA hybridization, DNA sensor

\section{Introduction}

Surface plasmon resonance (SPR) biosensors have become an important tool for characterizing and quantifying biomolecular interactions, because of their ability to measure biomolecular interactions directly, in real time and without the using labels [1-3]. However, this method, despite its many advantages, cannot ensure the detection of DNA sequences in subnanomolar concentrations without molecular label. To improve the detection limit of the SPR biosensors, a sandwich hybridization format can be used. In this format, the procedure consists of two steps: 1) identification of a target DNA by the selective hybridization with DNA probes immobilized on the sensor surface and 2) amplification of the sensor response by the additional hybridization step between a target DNA and so-called detection probe (itself or attached to an amplification agent) $[1,3-5]$. A key step to ensure the success of this signal amplification format is an appropriate choice of the amplification agent. In SPR method, a large macromolecule or a nanoobject (e.g., gold nanoparticle) can be used for this purpose.

Gold nanoparticles (AuNPs) possess many attractive features: they are nontoxic, cheap and can be easily modified by various chemicals or biomacromolecules $[4,6]$. Therefore, the choice of AuNPs fits well for the develop- ment of technologically simple, flexible and cheap method for amplification of the SPR sensor signal. Unfortunately, the use of AuNPs in buffer solutions that support the process of hybridization may be accompanied by the electrolyte-induced aggregation because a rather high ionic strength of the buffer solutions overcomes the electrostatic repulsion between nanoparticles [6, 7]. However, the modification of nanoparticle surface by DNA sequences increases steric hindrance and electrostatic repulsion between AuNPs that increases their stability [8]. It allows us to expand the range of ionic strength of solutions in which the use of nanoparticles becomes possible. If the ionic strength of the solution is high enough to ensure the efficient DNA hybridization, and the AuNPs do not undergo aggregation, it becomes possible to use AuNPs as molecular labels to enhance the sensor signal $[3-5,9]$.

In suspension of the modified AuNPs, their stabilization is observed when the inter-particle attractive and repulsive forces are balanced [6]. The interface environment alters the existing force balance leading to the surface aggregation of AuNPs. Therefore, adsorption of modified AuNPs is driven by both specific (hybridization of complementary DNA chains) and non-specific adsorption of modified nanoparticles on the sensor surface [10]. If the role of the latter becomes prevalent, an inten- 
sive aggregation of the modified AuNPs onto the sensor surface occurs, its regeneration and reuse become impossible. From this point of view, it is crucial to determine the conditions for selective and reversible interactions of the modified AuNPs with a bioselective element of the sensor.

Therefore, this study was aimed at the investigation of an influence of the oligonucleotides concentration on the process of their immobilization on the surface of gold nanoparticles (AuNPs), and revealing the features of interactions of the AuNPs modified by various oligonucleotides with oligonucleotides immobilized on the chip of the SPR-based DNAsensor.

\section{Methods and Materials}

\section{Reagents}

Urea, $\mathrm{KH}_{2} \mathrm{PO}_{4}$, 6-mercapto-1-hexanol were obtained from Fluka (Buchs, Switzerland). All solutions were made with deionized Milli-Q water.

For immobilization on a gold sensor surface, the single-stranded oligonucleotide $\mathbf{P 2}$ functionalized at the 5'-end with a thiol group through hexamethylene spacer (HS- $\left(\mathrm{CH}_{2}\right)_{6}{ }^{-}$ ACC CAC AAG CGC CGA CTG TTG) was used. Its sequence represents the fragment of the rpoB gene of Mycobacterium tuberculosis, the mutations of which lead to the drug resistance of the bacteria.

For hybridization with $\mathbf{P 2}$, the thiolated oligonucleotides T2-18m ( $\mathrm{HS}-\left(\mathrm{CH}_{2}\right)_{6}$-CAA CAG TCG GCG CTT GTG), T2-11m (HS$\left(\mathrm{CH}_{2}\right)_{6}$-CAA CAG TCG GC) and the unmodified oligonucleotide T2 (CAA CAG TCG GCG CTT GTG GGT) were applied. Notably, these three oligonucleotides possess a homological sequence; T2-18m is shorter than T2, but longer than $\mathbf{T} \mathbf{2 - 1 1 m}$. All listed oligonucleotides hybridize with the complementary oligonucleotide $\mathbf{P 2}$ in a very similar manner, but the different length of the sequences causes the different stability of the duplexes (Fig. 1).

For testing selectivity of the sensor response, the thiolated oligonucleotide mp-14 (HS- $\left(\mathrm{CH}_{2}\right)_{6}$-GCT GAA GGG CTT TT), which is non-complementary to $\mathbf{P 2}$, was used.

All oligonucleotides were obtained from Metabion International AG (Germany). The choice of the length and nucleotide sequence of the oligonucleotides was described elsewhere [5].

\section{Synthesis of AuNPs}

The preparation of AuNPs is performed through the reduction of tetrachloroaurate ions $\left(\mathrm{AuCl}_{4}^{-}\right)$by boiling in an aqueous sodium citrate solution [11]. First, $20 \mathrm{ml}$ of $1 \mathrm{mM}$ $\mathrm{HAuCl}_{4}$ are heated to a boil with constant stirring and reflux. Then, $2 \mathrm{ml}$ of $1 \%$ sodium citrate are added. Heating and stirring continued for $10 \mathrm{~min}$. Gold ions are reduced gradually, and the color of the solution becomes saturated red. The solution is cooled to room temperature. AuNPs obtained appear as practically monodispersed spherical structures with a size of about $10-15 \mathrm{~nm}$, which are stabilized by weakly bound citrate ions. AuNPs are characterized by the plasmonic absorption band at approximately $520 \mathrm{~nm}$.

\section{Modification of AuNPs}

For reliable immobilization of thiolated oligonucleotides onto AuNPs, an ability of their $\mathrm{SH}$-groups to form covalent bonds with gold 


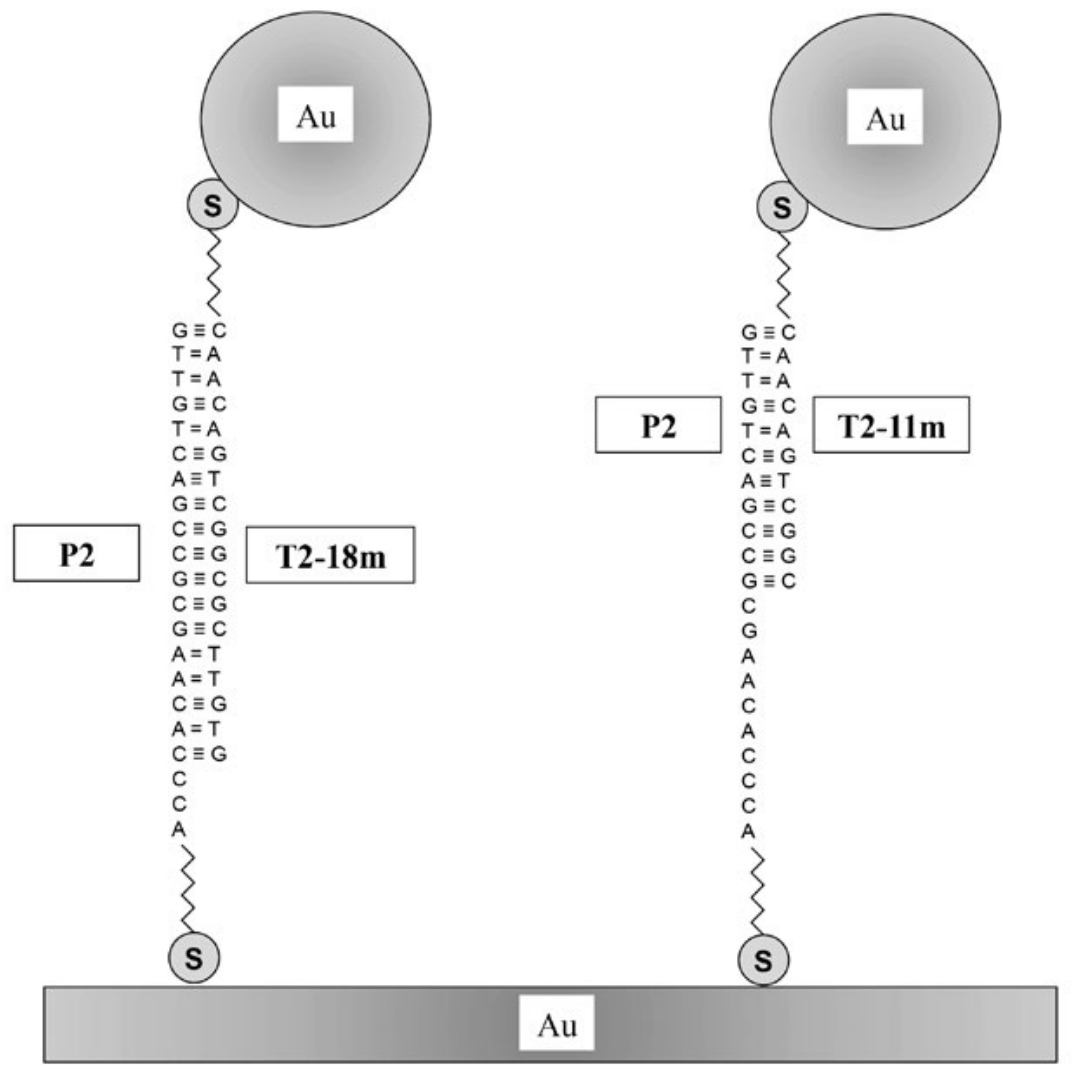

Fig. 1. Schematic presentation of the hybridization between oligonucleotides P2 immobilized on the sensor chip and oligonucleotides $\mathbf{T} \mathbf{2}-\mathbf{1 8 m}$ or $\mathbf{T 2} \mathbf{- 1 1} \mathrm{m}$, which are part of the modified AuNPs. For clarity, AuNPs are shown as modified by the single oligonucleotide. surface was used. To determine a level of the oligonucleotide immobilization on the surface of AuNPs, the procedure based on the property of the SYBR Green II fluorescent dye to increase drastically its fluorescence in the presence of a single-stranded oligonucleotide was applied. Namely, a level of fluorescence of SYBR Green II (proportional to the oligonucleotide concentration) in solutions before and after immobilization (initial concentration of oligonucleotides and concentration of unbound oligonucleotides) is measured. The difference is the molar concentration of the bound oligonucleotides. The division of this value to a molar concentration of nanoparticles gives an average num- ber of oligonucleotides immobilized on a single nanoparticle.

The AuNPs modification by the thiolated oligonucleotides is carried out by incubation of AuNPs with the oligonucleotides overnight in $0.1 \times \mathrm{SSC}$ buffer solution $(1.5 \mathrm{mM}$ sodium citrate, $15 \mathrm{mM} \mathrm{NaCl}, \mathrm{pH}$ 7) at room temperature. After that, nanoparticles are separated from the unbound oligonucleotides by centrifugation at 12,000 rpm for $30 \mathrm{~min}[12,13]$. The supernatant is used to determine a level of the oligonucleotide immobilization on the surface of AuNPs by SynergyHT (BioTek) Microplate Reader, and the precipitate is analyzed by UV-Vis spectra analysis using spectrophotometer Nanodrop2000. 
4. SPR spectrometry of the processes of oligonucleotide immobilization and hybridization on the sensor surface

The two-channel SPR spectrometer "Plasmon 6 " was used. This optoelectronic device in the Kretchmann's optical configuration was developed at V. Ye. Lashkaryov Institute of Semiconductor Physics of National Academy of Sciences of Ukraine. The $45 \mathrm{~nm}$ thick gold layer on a glass plate serves as a sensor surface. Prior to modification, gold surface of the glass plate is cleaned with freshly prepared piranha solution (3:1 mixture of concentrated $\mathrm{H}_{2} \mathrm{SO}_{4}$ and $30 \% \mathrm{H}_{2} \mathrm{O}_{2}$; WARNING: piranha solution reacts violently with organic compounds and must be handled with extreme care) at room temperature for $2 \mathrm{~min}$, then rinsed thoroughly with distilled and deionized water, and dried in the air. The cleaned plate is mounted on the spectrometer prism by using immersion liquid of the same refractive index as the prism and the plate. The flow rate (usually $40 \mu 1 \mathrm{~min}^{-1}$ ) through the measuring flow cell is controlled by the peristaltic pump "Ismatec". The preparation of bioselective element of DNA-sensor includes two main steps: immobilization of oligonucleotide probe and passivation of the free chip surface. For immobilization of the thiolated probe, $120 \mu \mathrm{l}$ of $1 \mu \mathrm{M} \mathrm{P2}$ in $0.5 \mathrm{M} \mathrm{KH}_{2} \mathrm{PO}_{4}(\mathrm{pH} 3.8)$ are injected into the measuring flow cell and exposed for $1 \mathrm{~h}$. After that, the sites on the gold surface free from immobilized P2, were blocked by $1 \mathrm{mM}$ aqueous solution of 6-mercapto-1-hexanol [14].

At the beginning of the hybridization experiment, the measuring flow cell of SPR spectrometer with the prepared bioselective element of DNA-sensor is thoroughly washed by the running buffer solution, for example, $2 \times \mathrm{SSC}$ (30 mM sodium citrate, $300 \mathrm{mM} \mathrm{NaCl}, \mathrm{pH}$ 7) to obtain a stable sensor signal. At the next step, $120 \mu 1$ of target solution in the running buffer are injected into the measuring flow cell and exposed for $10 \mathrm{~min}$. To reuse the bioselective element of DNA-sensor, it is necessary to disrupt the bonds between hybridized DNA chains. To implement thermal regeneration, a block of thermal regulation of the measuring flow cell, which controls temperature in a range from $20{ }^{\circ} \mathrm{C}$ to $60{ }^{\circ} \mathrm{C}$, was developed (Patent of Ukraine O. 110131 issued September 26, 2016, IPC (2015.01) G01N 21/55). After hybridization at a room temperature, and the measuring of the initial biosensor response, the heating to the selected temperature is provided for $5 \mathrm{~min}$ at continuous flow of the buffer solution. Dehybridized nucleic acids are removed from the measuring cell. Then, the heating is switched off and the temperature in the cell decreases to room temperature. After that a final determination of the sensor response is performed. By comparing the obtained value with the initial one, the efficiency of the regeneration (or the portion of double-stranded complexes disrupted due to this procedure) can be defined. For chemical regeneration, the injection of $120 \mu 1$ of $8 \mathrm{M}$ Urea is used.

\section{Results and Discussion}

An influence of the initial concentration of oligonucleotides on the level of their immobilization on the surface of AuNPs was investigated. Fig. 2A shows that the increase in the initial oligonucleotide concentration resulted in higher level of their immobilization. Up to $200 \mathrm{nM}$ the dependence is close to linear, and then the approach to saturation can be ob- 
served. In contrast, the efficiency of immobilization (a ratio of the immobilized oligonucleotide concentration to the initial one) gradually decreases along with the increase of the initial oligonucleotide concentration (Fig. 2B).

Given an average diameter of the spherical AuNP $(13 \mathrm{~nm})$ and its surface area $\left(530 \mathrm{~nm}^{2}\right)$, the maximum surface density of the immobilized oligonucleotides $\mathbf{T 2 - 1 8 m}$ was $\sim 26$ molecules per particle, or $\sim 0.5 \times 10^{13}$ molecules $\mathrm{cm}^{-2}$, or $\sim 8 \mathrm{pmol} \mathrm{cm}^{-2}$. It is well established that salt concentration determines the loading capacity of thiolated DNA by AuNPs, where a higher salt concentration results in more DNA molecules adsorbed. When the $\mathrm{NaCl}$ concentration is close to $1 \mathrm{M}, \sim 110$ thiolated DNA strands can be immobilized on each $13 \mathrm{~nm}$ AuNP [15-17]. In our previous investigations, the levels of oligonucleotide immobilization on the plain gold surface of the SPR chip were $28 \mathrm{pmol} \mathrm{cm}^{-2}$ or $1.7 \times 10^{13}$ molecules $\mathrm{cm}^{-2}$ for oligonucleotides $\mathbf{P 2}$ [5], and $7.6 \times 10^{12}$ molecules $\mathrm{cm}^{-2}$ for oligonucleotides mod-Ph [18]. When $50 \mathrm{nM} \mathbf{P 2}-\mathbf{C y} 3$ in $0.1 \times \mathrm{SSC}$ was
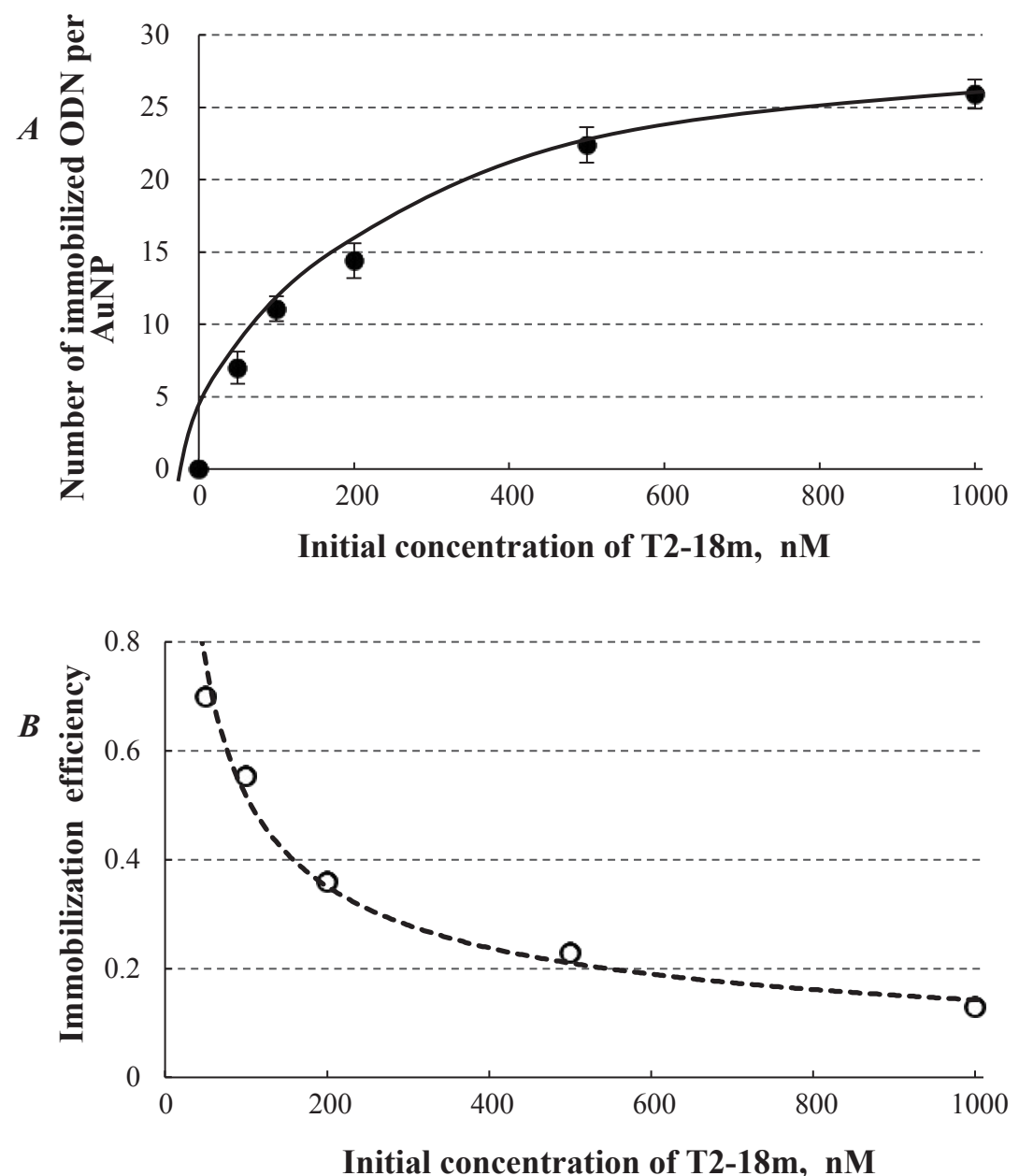

Fig. 2. The influence of the initial oligonucleotide (ODN) T2-18m concentration on the level of immobilization on the surface of AuNPs (A), and the efficiency of immobilization (B). 
used for immobilization on the spherical surface of AuNPs, the surface density was approximately 13.5 oligonucleotides per nanoparticle or $2.5 \times 10^{12}$ molecules $/ \mathrm{cm}^{2}$ [12]. On the one hand, electrostatic repulsion between DNA chains on a flat surface is stronger, which reduces the level of immobilization, and, on the other hand, the process of immobilization on the flat surface was held at $0.5 \mathrm{M} \mathrm{KH}_{2} \mathrm{PO}_{4}$. It significantly shields the charges of phosphate residues of DNA, and thus contributes to more effective immobilization. Therefore, the obtained values of the surface density of the immobilized oligonucleotides $\mathbf{T} \mathbf{2}-\mathbf{1 8 m}$ are in good agreement with the data presented by other authors as well as with our previously published results for both cases of surface curvature.

Further application of the modified AuNPs is associated with hybridization between the oligonucleotides immobilized on the AuNPs surface and other (complementary) sequences of nucleic acids. The efficient hybridization occurs only under relatively high ionic strength. However, in this case the equilibrium between van der Waals attractive and electrostatic repulsive forces in the AuNPs dispersion is disturbed and electrolyte-induced aggregation occurs. The dispersed AuNPs exhibit only a single peak at $\sim 520 \mathrm{~nm}$, whereas particle aggregates show two light extinction maxima. As the interparticle spacing decreases, the first peak becomes weaker, while the second peak intensifies and shifts to longer wavelengths $[6,7]$.

As it was observed earlier, the stability of modified AuNPs depends on a charge which is carried by the modifying compounds, and the negatively charged compounds increase the stability of nanoparticle dispersion [19, 20]. Therefore, AuNPs modified by negatively charged oligonucleotides would be more stable against the electrolyte-induced aggregation than unmodified ones. Indeed, AuNPs with a higher surface density of the immobilized oligonucleotides demonstrated a higher stability. Their level of light extinction at $520 \mathrm{~nm}$ remained unchanged up to $0.5 \times \mathrm{SSC}$ [9]. These results allow using the modified AuNPs for DNA hybridization because the concentration of the buffer solution can provide rather stringent and highly selective conditions for the hybridization process $[18,21]$.

To investigate the influence of the sequence and length of the oligonucleotides, which were used for the modification of AuNPs, on the level of their interactions with the oligonucleotides P2 immobilized on the chip surface of the SPR-based DNA-sensor, three different oligonucleotides were applied (T2-18m, T2$11 \mathrm{~m}$ and $\mathbf{m p - 1 4 )}$. After overnight incubation of $1 \mu \mathrm{M}$ solution of each oligonucleotide with $5 \mathrm{nM}$ AuNPs and the separation of nanoparticles from the unbound oligonucleotides by two-step centrifugation, the concentration of the obtained AuNPs was determined spectrophotometrically at $520 \mathrm{~nm}$. Losses at the cleaning procedure constituted $15-30 \%$. Finally, $0.25 \mathrm{nM}$ solution of AuNPs modified by either mp-14, T2-18m or T2-11m was injected into the measuring flow cell of the DNA-sensor, and the sensor response was recorded.

To reuse a bioselective element of the DNA-sensor after hybridization step, thermal or chemical regeneration could be applied. The strength of bonding between two hybridized oligonucleotides is easy to predict, because it depends on the number of comple- 
mentary base pairs. This strength can be expressed as thermodynamic parameters of hybridization or melting temperature $\left(T_{m}\right)$ of a double-stranded complex. Using the DINAMelt web server http://mfold.rna.albany.edu/?q=DINAMelt [22] the values of the melting temperature $\left(\mathrm{T}_{\mathrm{m}}\right)$ of doublestranded oligonucleotides of varying degree of complementarity were calculated for homogeneous state (in solution) for the next oligonucleotides. P2 and T2 are fully complementary 21-mers, T2-18 and T2-11 are, respectively, 18- and 11-mer shorter fragments of T2. So, T2-18 and T2-11 - partially complementary to $\mathbf{P 2}$, and therefore the strength of their double-stranded complexes with $\mathbf{P 2}$ is smaller and $\mathrm{T}_{\mathrm{m}}$ is lower than that of completely complementary pair P2-T2 (Table 1). And the difference in 3 nucleotides between T2 and T2-18 leads to the decrease in $T_{m}$ value of their duplex with $\mathbf{P 2}$ by approximately $5{ }^{\circ} \mathrm{C}$, whereas the difference in $10 \mathrm{nu}-$ cleotides between T2 та T2-11 - by $\sim 25^{\circ} \mathrm{C}$. Table 1 also shows the direct dependence of $\mathrm{T}_{\mathrm{m}}$ on ionic strength of the medium (multiplicity of SSC buffer solution).

Oligonucleotides T2-11m and T2-18m have the same nucleotide sequence as oligonucleotides T2-11 and T2-18, respectively, but they were additionally modified at the 5 '-end by
SH-group for reliable immobilization on gold surfaces. AuNPs modified by the oligonucleotides mp14, which are not complementary to P2, were used as a control.

For thermal regeneration, a block of thermal regulation of the measuring flow cell was used. As expected, the injection of the non-complementary oligonucleotides mp14 as a part of the modified nanoparticles into the measuring cell of the SPR biosensor did not cause any sensor response (data not shown). It indicates the absence of non-specific adsorption of the nanoparticles modified by non-complementary oligonucleotides. As shown in Fig. 3 and 4, the injection of both complementary oligonucleotides as parts of the modified nanoparticles into the measuring cell of the DNA-sensor at room temperature caused significant and approximately the same sensor response, indicating a successful hybridization with P2 immobilized on the sensor chip. However, the elevation of temperature in the thermo-regulated measuring cell to $45^{\circ} \mathrm{C}$ and subsequent cooling to the initial temperature affected the stability of doublestranded complexes formed with $\mathbf{T 2 - 1 8 m}$ or T2-11m in different way. In case of a longer oligonucleotide (their duplexes are characterized by a higher $\mathrm{T}_{\mathrm{m}}$ ), the sensor signal returned almost to the level observed before heating. That is, the temperature elevation to $45^{\circ} \mathrm{C}$ was

Table 1. The values of melting temperature of the pairs of studied oligonucleotides calculated for homogeneous state (in solution) for different ionic strength (multiplicity of SSC buffer solution).

\begin{tabular}{|l|c|c|c|}
\hline \multicolumn{1}{|c|}{ Pairs of oligonucleotides } & $\mathrm{T}_{\mathrm{m}}$ in $0.5 \times \mathrm{SSC},{ }^{\circ} \mathrm{C}$ & $\mathrm{T}_{\mathrm{m}}$ in $1 \times \mathrm{SSC},{ }^{\circ} \mathrm{C}$ & $\mathrm{T}_{\mathrm{m}}$ in $2 \times \mathrm{SSC},{ }^{\circ} \mathrm{C}$ \\
\hline P2 та T2 & 62.5 & 65.7 & 69.1 \\
P2 та T2-18 & 57.6 & 60.8 & 64.1 \\
P2 та T2-11 & 37.8 & 40.6 & 43.6 \\
\hline
\end{tabular}

All calculations are performed for $22{ }^{\circ} \mathrm{C}, 0 \mathrm{M} \mathrm{Mg}^{2+}$, and $100 \mathrm{nM}$ concentration of the oligonucleotides. 

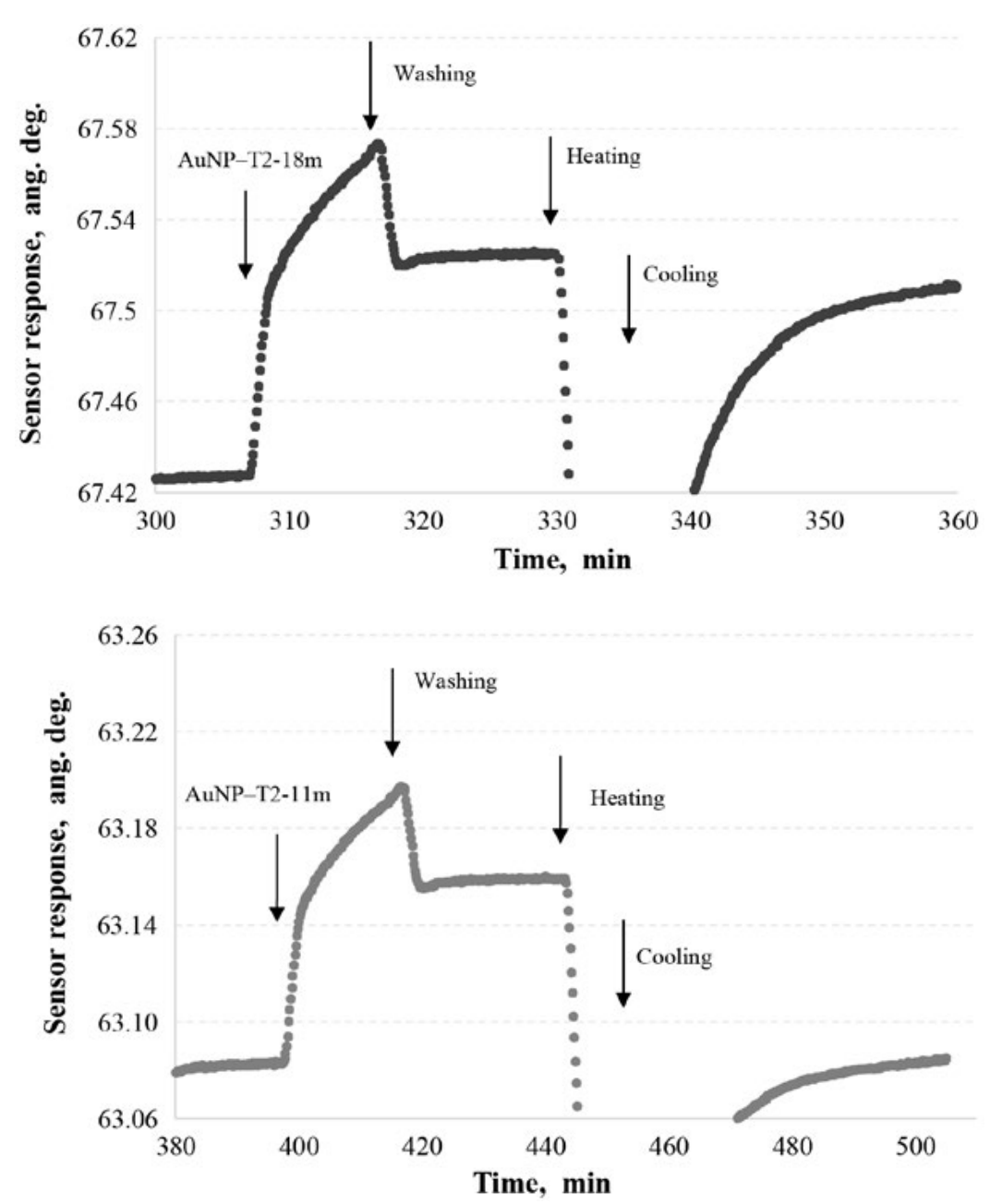

Fig. 3. SPR sensogram representing hybridization between oligonucleotides $\mathbf{P 2}$ immobilized on the sensor chip and oligonucleotides $\mathbf{T} \mathbf{2}-\mathbf{1 8 m}$, which are a part of the modified AuNPs, as well as the impact of heating to $45{ }^{\circ} \mathrm{C}$ and subsequent cooling to the initial temperature on the stability of the double-stranded complexes formed. The reaction medium is $0.5 \times \mathrm{SSC}$.

Fig. 4. SPR sensogram representing hybridization between oligonucleotides $\mathbf{P 2}$ immobilized on the sensor chip and oligonucleotides T2-11m, which are a part of the modified AuNPs, as well as the impact of heating to $45{ }^{\circ} \mathrm{C}$ and subsequent cooling to the initial temperature on the stability of the double-stranded complexes formed. The reaction medium is $0.5 \times \mathrm{SSC}$.

insufficient to melt duplex P2/T2-18m and to regenerate the bioselective element of the DNAsensor (Fig. 3). The thermal regeneration after hybridization of $\mathbf{P 2}$ with $\mathbf{T 2}-\mathbf{1 8 m}$ immobilized on the surface of AuNPs requires heating above $60{ }^{\circ} \mathrm{C}$, and was not applied because of technical limitations of block thermal regulation of the measuring flow cell.

In case of the short oligonucleotides T2$11 \mathrm{~m}$ (their duplexes are characterized by $\mathrm{T}_{\mathrm{m}}$ below $45^{\circ} \mathrm{C}$ ), after the temperature elevation to $45^{\circ} \mathrm{C}$ and subsequent cooling to the initial temperature the sensor signal returned to the level observed before hybridization. That is, heating to $45{ }^{\circ} \mathrm{C}$ caused the efficient regeneration of the bioselective element by thermal destruction of the duplexes P2/T2-11m (Fig. 4).

Fig. 5 shows the sensograms representing the hybridization between oligonucleotides $\mathbf{P 2}$ immobilized on the sensor chip and oligonucleotides, which are a part of the modified AuNPs. These sensograms were obtained at room temperature using $8 \mathrm{M}$ Urea for chemi- 


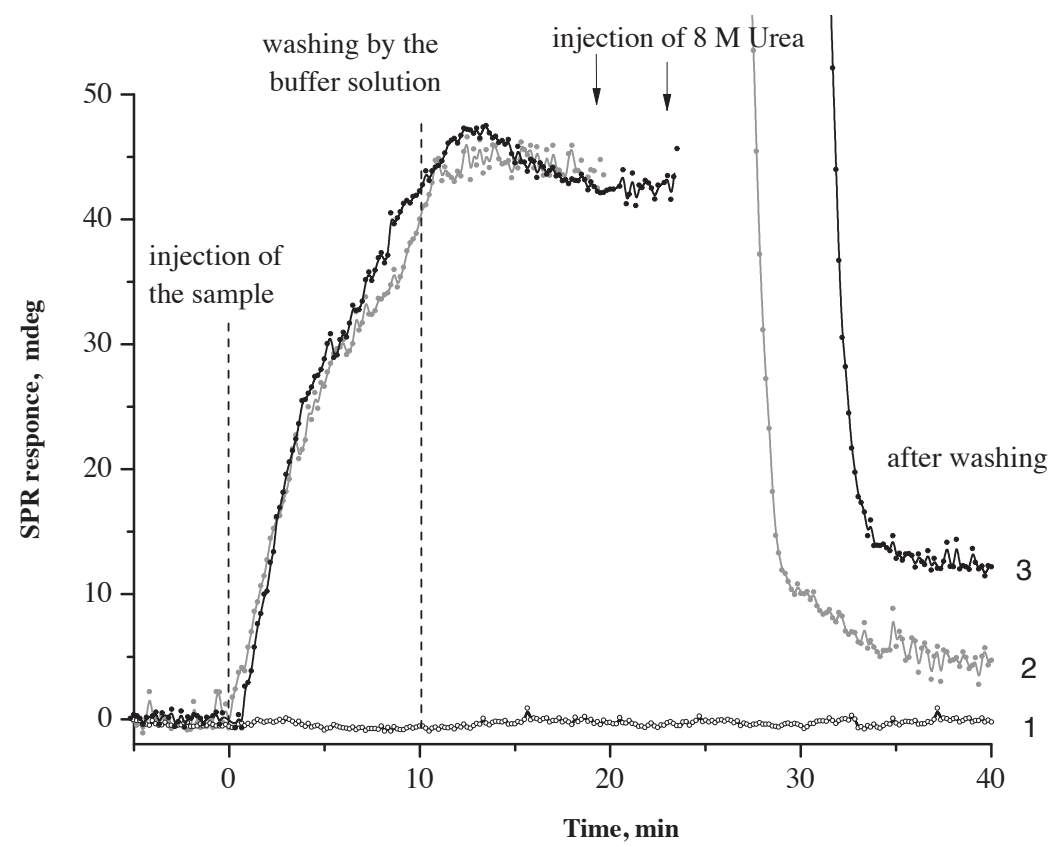

Fig. 5. SPR sensograms representing the hybridization between oligonucleotides P2 immobilized on the sensor chip, and oligonucleotides, which are a part of the modified AuNPs, as well as the impact of $8 \mathrm{M}$ urea on the stability of the doublestranded complexes formed. AuNPs were modified by mp14 (1), or T2$11 \mathrm{~m}$ (2), or T2-18m (3). The reaction medium is $0.5 \times \mathrm{SSC}$. cal regeneration of the bioselective element of the DNA-sensor. The injection of the noncomplementary oligonucleotides mp14 as a part of the modified nanoparticles, as expected, did not cause any sensor response (curve 1). The injection of both complementary oligonucleotides as a part of the modified AuNPs into the measuring cell of the DNA-sensor caused significant and approximately the same sensor response, indicating a successful hybridization with P2. In case of AuNPs modified by the short oligonucleotides T2-11m (curve 2), the injection of $8 \mathrm{M}$ Urea resulted in rather efficient regeneration, which is comparable with that at the hybridization of free standing (without AuNPs) completely complementary oligonucleotides $\mathbf{T} 2[5,21,23]$. Although in case of AuNPs modified by longer oligonucleotides T2-18m (curve 3) a significant part of the double-stranded complexes $(\sim 70 \%)$ was destroyed using $8 \mathrm{M}$ Urea, a less efficient regeneration was observed. This relatively low efficiency of regeneration cannot be explained only by stronger specific interactions of $\mathbf{P 2}$ with 18-mer (compared with 11-mer), because the duplex of $\mathbf{P 2}$ with completely complementary T2 (21-mer without AuNPs) is easily disrupted by $8 \mathrm{M}$ Urea. Probably, it can be explained by the contribution of nonspecific interactions of AuNPs with the bioselective element of the DNA-sensor (in addition to P2/T2-18m hybridization). Therefore, a search for conditions of more efficient chemical regeneration after hybridization of $\mathbf{P 2}$ with T2-18m immobilized on the surface of AuNPs should be continued.

Taking into account that in the field of SPR sensors, the limit of detection (LOD) is usually defined as the concentration of analyte that produces sensor response corresponding to 3 standard deviations of sensor response measured for a blank sample [1, 24], LOD for 
AuNPs modified by $\mathbf{T 2}-\mathbf{1 1} \mathrm{m}$ or $\mathbf{T 2} \mathbf{2} \mathbf{- 1 8 m}$ was calculated to be $\sim 10 \mathrm{pM}$. Previously, the detection of $20 \mathrm{nM} \mathrm{T2}$ (free standing) by the same P2-based DNA-sensor was shown [9]. Therefore, the calculated LOD is in a good agreement with our earlier prediction that at using AuNPs modified by specific oligonucleotides, a response of the DNA hybridization sensor based on the SPR spectrometer "Plasmon 6" can be amplified by over 1000 times [9]. Additionally, this LOD value is 2 orders of magnitude smaller, than the level of detection of T2, which was achieved using the impedimetric P2-based DNA-sensor [25].

\section{Conclusions}

The results of the present study show that a level of the oligonucleotide immobilization on the AuNPs surface directly depends on the initial oligonucleotide concentration, whereas the initial oligonucleotides concentration and the efficiency of their immobilization on the surface of AuNPs demonstrate the inverse relationship. The obtained values of the surface density of the oligonucleotides immobilized on the surface of AuNPs are in good agreement with the data presented by other authors as well as with our previously published results.

Using SPR-based DNA-sensor, the efficient hybridization between oligonucleotides immobilized on the sensor chip and complementary oligonucleotides of various length immobilized on AuNPs was demonstrated. In case of the AuNPs modified by the short oligonucleotides (T2-11 m), the efficient thermal and chemical regenerations of the bioselective element of the DNA-sensor were achieved. In case of AuNPs modified by longer oligonucleotides (T2-18m), chemical regeneration of the bioselective element of the DNA-sensor by 8 M Urea was not so efficient, probably due to a contribution of nonspecific interactions of AuNPs with the bioselective element of the biosensor.

Additionally, our prediction that at use of AuNPs modified by specific oligonucleotides a response of the DNA hybridization sensor based on the SPR spectrometer "Plasmon 6" can be amplified by over 1000 times [9] was confirmed also. The efficient hybridization of the oligonucleotides of various lengths immobilized on AuNPs with the oligonucleotides immobilized on the sensor surface as well as the possibility of thermal and chemical regenerations allow multi-use of the sensor along with a strong amplification of the sensor signal.

\section{Funding}

This work was partially supported by STCU project N 6044; 2015.

\section{REFERENCES}

1. Homola J. Surface plasmon resonance sensors for detection of chemical and biological species. Chem Rev. 2008;108(2):462-93.

2. Rich RL, Myszka DG. Survey of the year 2007 commercial optical biosensor literature. J Mol Recognit. 2008;21(6):355-400.

3. Šipová H, Homola J. Surface plasmon resonance sensing of nucleic acids: a review. Anal Chim Acta. 2013;773:9-23.

4. Merkoçi A. Nanoparticles-based strategies for DNA, protein and cell sensors. Biosens Bioelectron. 2010; 26(4):1164-77.

5. Rachkov A, Patskovsky S, Soldatkin A, Meunier M. Surface plasmon resonance detection of oligonucleotide sequences of the rpoB genes of Mycobacterium tuberculosis. Talanta. 2011;85(4):2094-9.

6. Ghosh SK, Pal T. Interparticle coupling effect on the surface Plasmon resonance of gold nanoparti- 
SPR investigation of DNA hybridization using modified AuNPs

cles: from theory to applications. Chem Rev. 2007; 107(11):4797-862.

7. Zhao W, Brook MA, Li Y. Design of gold nanoparticle-based colorimetric biosensing assays. Chembiochem. 2008;9(15):2363-71.

8. Storhoff JJ, Elghanian R, Mucic RC, Mirkin CA, Letsinger $R L$. One-pot colorimetric differentiation of polynucleotides with single base imperfections using gold nanoparticle probes. J Am Chem Soc. 1998; 120(9): 1959-64.

9. Matsishin M, Rachkov A, Lopatynskyi A, Chegel V, Soldatkin A, El'skaya A. Selective amplification of SPR biosensor signal for recognition of rpob gene fragments by use of gold nanoparticles modified by thiolated DNA. Nanoscale Res Lett. 2017;12(1):252.

10. D'Agata R, Corradini R, Ferretti C, Zanoli L, Gatti $M$, Marchelli R, Spoto G. Ultrasensitive detection of non-amplified genomic DNA by nanoparticleenhanced surface plasmon resonance imaging. Biosens Bioelectron. 2010;25(9):2095-100.

11. Turkevitch J, Stevenson PC, Hillier J. A study of the nucleation and growth processes in the synthesis of colloidal gold. Discuss Faraday Soc. 1951; 11: 55-75.

12. Matsishin M, Rachkov A, Losytskyy M, Soldatkin A. Experimental approach using covalently attached fluorophore for quantification of oligonucleotide immobilization on gold nanoparticles. Colloid Interface Sci Commun. 2014; 1: 35-8.

13. Matsishin M, Rachkov A, Halushkina A, Soldatkin A. Investigations of the level oligonucleotide immobilization on the surface of gold nanoparticles using experimental approach with fluorophore Cy3. Sens Electron Microsyst Technol. 2014; 11(3): 31-41.

14. Herne TM, Tarlov MJ. Characterization of DNA probes immobilized on gold surfaces. $J$ Am Chem Soc. 1997; 119(38): 8916-20. J. Am. Chem. Soc. 1997, 119(38), pp 8916-8920.

15. Demers LM, Mirkin CA, Mucic RC, Reynolds RA $3 r d$, Letsinger RL, Elghanian R, Viswanadham $G$. A fluorescence-based method for determining the surface coverage and hybridization efficiency of thiol-capped oligonucleotides bound to gold thin films and nanoparticles. Anal Chem. 2000;72(22): 5535-41.
16. Hurst SJ, Lytton-Jean AK, Mirkin CA. Maximizing DNA loading on a range of gold nanoparticle sizes. Anal Chem. 2006;78(24):8313-8.

17. Liu J. Adsorption of DNA onto gold nanoparticles and graphene oxide: surface science and applications. Phys Chem Chem Phys. 2012;14(30): 10485-96.

18. Matsishin MJ, Ushenin IuV, Rachkov AE, Solatkin AP. SPR detection and discrimination of the oligonucleotides related to the normal and the hybrid bcr-abl genes by two stringency control strategies. Nanoscale Res Lett. 2016;11(1):19.

19. Chegel V, Rachkov O, Lopatynskyi A, Ishihara S, Yanchuk I, Nemoto Y, Hill JP, Ariga K. Gold nanoparticles aggregation: drastic effect of cooperative functionalities in a single molecular conjugate. J Phys Chem C. 2012; 116(4): 2683-90.

20. Rachkov A, Matsishin M, Chegel V, Lopatynskyi A, Yanchuk I, Soldatkin A. Investigations of aggregation stability of gold nanoparticles at their interactions with compounds bearing thiol and/or amino functional groups. Chem Sens. 2014; 4: 16.

21. Rachkov A, Patskovsky S, Soldatkin A, Meunier M. Discrimination of single base mismatched oligonucleotides related to the rpoB gene of Mycobacterium tuberculosis using a surface plasmon resonance biosensor. Biotechnol Appl Bioc. 2013; 60(4): 453-8.

22. Markham NR, Zuker M. DINAMelt web server for nucleic acid melting prediction. Nucleic Acids Res. 2005;33(Web Server issue):W577-81.

23. Rachkov A, Holodova Y, Ushenin Y, Miroshnichenko D, Telegeev G, Soldatkin A. Development of bioselective element of SPR spectrometer for monitoring of oligonucleotide interactions and comparison with thermody-namic calculations. Sens Lett. 2009; 7(5): 957-61.

24. Thomsen V, Schatzlein D, Mercuro D. Limits of detection in spectroscopy. Spectroscopy. 2003, 18(12): 112-4.

25. Matsishin M, Rachkov A, Errachid A, Dzyadevych S, Soldatkin A. Development of impedimetric DNA biosensor for selective detection and discrimination of oligonucleotide sequences of the rpoB gene of 
Mycobacterium tuberculosis. Sensor Actuat BChem. 2016; 222: 1152-8.

\section{Дослідження гібридизації ДНК на поверхні сенсора поверхневого плазмонного резонансу з використанням наночастинок золота, модифікованих специфічними олігонуклеотидами}

М. Й. Мацишин, А. І. Кучеров, Ю. В. Ушенін, О. М. Ляпін, А. М. Лопатинський, В. І. Чегель, О. Е. Рачков

Мета. Вивчення впливу концентрації олігонуклеотидів на їх іммобілізацію на поверхні наночастинок золота (AuNPs) та виявлення деяких особливостей взаємодії AuNPs, модифікованих різними олігонуклеотидами, 3 олігонуклеотидами, іммобілізованими на чипі ДНКсенсора поверхневого плазмонного резонансу. Методи. Рівень іммобілізації олігонуклеотидів на поверхні AuNPs досліджували флуоресцентною спектрометрією. Взаємодія стабілізованих цитратом AuNPs, модифікованих олігонуклеотидами, з олігонуклеотидами, іммобілізованими на чипі ДНК-сенсора, вивчали за допомогою спектрометрії поверхневого плазмонного резонансу. Результати. При іммобілізації олігонуклеотидів на поверхні стабілізованих цитратом AuNPs початкова концентрація олігонуклеотидів впливає на рівень їх іммобілізації: до 200 нМ залежність була близькою до лінійної, а потім спостерігали наближення до насичення ( 26 молекул на одну частинку або $\sim 0,5 \times 10^{13}$ молекул $\left.\mathrm{cm}^{-2}\right)$. На відміну від цього, ефективність іммобілізації поступово зменшується разом із збільшенням початкової концентрації олігонуклеотидів. Використовуючи ДНК-сенсор поверхневого плазмонного резонансу, продемонстрували ефективну гібридизацію між олігонуклеотидами, іммобілізованими на сенсорному чипі, та комплементарними олігонуклеотидами різної довжини (короткі T2-11m і довгі T2-18m), іммобілізованими на поверхні AuNPs. У випадку AuNPs, модифікованих короткими олігонуклеотидами, були досягнуті ефективні термічна та хімічна регенерація біоселективного елемента ДНК-сенсора. Висновки. Рівень іммобілізації олігонуклеотидів на поверхні AuNPs прямо пропорційно залежить від вихідної концентрації олігонуклеотидів, тоді як вихідна концентрація олігонуклеотидів та ефективність їх іммобілізації на поверхні AuNPs демонструють зворотний зв'язок. Ефективна гібридизація олігонуклеотидів різної довжини, іммобілізованих на AuNPs, з олігонуклеотидами, іммобілізованими на поверхні сенсора, а також можливість термічної або хімічної регенерації дозволяють багаторазово використовувати сенсор та досягати величезного підсилення сенсорного сигналу.

К л юч о в і с л о в а: наночастинки золота, олігонуклеотиди, іммобілізація, поверхневий плазмонний резонанс, гібридизація ДНК, ДНК-сенсор.

\section{Исследование гибридизации ДНК на поверхности сенсора поверхностного плазмонного резонанса с использованием наночастиц золота, модифицированных специфическими олигонуклеотидами}

М. И. Мацишин, А. И. Кучеров, Ю. В. Ушенин, А. М. Ляпин, А. Н. Лопатинский, В. И. Чегель, А. Э. Рачков

Цель. Изучение влияния концентрации олигонуклеотидов на их иммобилизацию на поверхности наночастиц золота (AuNPs) и выявление некоторых особенностей взаимодействия AuNPs, модифицированных различными олигонуклеотидами, с олигонуклеотидами, иммобилизованными на чипе ДНК-сенсора поверхностного плазмонного резонанса. Методы. Уровень иммобилизации олигонуклеотидов на поверхности AuNPs исследовали флуоресцентной спектрометрией. Взаимодействие стабилизированных цитратом AuNPs, модифицированных олигонуклеотидами, с олигонуклеотидами, иммобилизованными на чипе ДНК-сенсора, изучали с помощью спектрометрии поверхностного плазмонного резонанса. Результаты. При иммобилизации олигонуклеотидов на поверхности стабилизированных цитратом AuNPs начальная концентрация олигонуклеотидов влияет на уровень их иммобилизации: до 200 нМ зависимость была близка к линейной, а затем наблюдали приближение к насыщению ( 26 молекул на одну частицу или $\sim 0,5 \times 10^{13}$ молекул $\mathrm{cm}^{-2}$ ). В отличие от этого, эффективность иммобилизации постепенно уменьшается вместе с увеличением начальной концентрации олигонуклеотидов. Используя ДНК-сенсор поверхностного плаз- 
монного резонанса, продемонстрировали эффективную гибридизацию между олигонуклеотидами, иммобилизованными на сенсорном чипе, и комплементарными олигонуклеотидами различной длины (короткие Т2$\mathbf{1 1 m}$ и длинные T2-18m), иммобилизованными на поверхности AuNPs. B случае AuNPs, модифицированных короткими олигонуклеотидами, были достигнуты эффективные термическая и химическая регенерация биоселективного элемента ДНК-сенсора. Выводы. Уровень иммобилизации олигонуклеотидов на поверхности AuNPs прямо пропорционально зависит от исходной концентрации олигонуклеотидов, тогда как исходная концентрация олигонуклеотидов и эффективность их иммобилизации на поверхности
AuNPs демонстрируют противоположную связь. Эффективная гибридизация олигонуклеотидов различной длины, иммобилизованных на AuNPs, с олигонуклеотидами, иммобилизованными на поверхности сенсора, а также возможность термической или химической регенерации позволяют многократно использовать сенсор и достигать огромного усиления сенсорного сигнала.

К л ю ч е в ы е с л о в а: наночастицы золота, олигонуклеотиды, иммобилизация, поверхностный плазмонный резонанс, гибридизация ДНК, ДНК-сенсор.

Received 04.07.2017 